\title{
GAMBARAN KARIES GIGI MOLAR PERTAMA PERMANEN PADA SISWA - SISWI SEKOLAH DASAR NEGERI 13 PALEMBANG TAHUN 2018
}

\author{
Listrianah$^{1}$, R.A.Zainur ${ }^{2}$, Levi Saputri Hisata ${ }^{3}$ \\ Email :Listrianah@yahoo.com
}

Diterima : 28 Desember 2018 Direvisi: 15 Januari 2019 Disetujui: 21 Januari 2019

\begin{abstract}
Abstrak
Molar pertama permanen merupakan gigi yang sangat rentan karies. Hal ini disebabkan gigi merupakan gigi permanen yang pertama erupsi, disamping itu bentuk anatomis yang mempunyai fit dan fissure yang dalam memudahkan penumpukan sisa makanan dan mikroorganisme yang sukar dibersihkan dengan cara menyikat gigi, sehingga mudah terjadi karies. Maka dari itu, penelitian ini berjudul Gambaran Karies Gigi Molar Pertama Permanen sspada Siswa - Siswi Sekolah Dasar Negeri 13 Palembang Tahun 2018.Tujuan penelitian ini diketahui gambaran karies gigi molar pertama permanen pada Siswa - Siswi Sekolah Dasar Negeri 13 Palembang Tahun 2018.Jenis penelitian yang digunakan adalah penelitian deskriptif dengan pendekatan survey. Analisa data yang digunakan adalah analisa univariate. Pengambilan sampel penelitian ini menggunakan metode purposive sampling. Subjek penelitian adalah anak-anak kelas I sampai V SD Negeri 13 Palembang berjumlah 185 anak. Hasil penelitian diketahui jumlah karies gigi molar pertama permanen sebanyak 106 (57\%) anak, karies gigi molar pertama permanen berdasarkan usia, 6 tahun sebanyak 1 (4\%) anak, pada usia 7 tahun sebanyak 8 (47\%) anak, pada usia 8 tahun sebanyak $44(77 \%)$, pada usia 9 tahun sebanyak 31 (69\%) anak, pada usia 10 tahun sebanyak 18 (64\%) anak, dan usia 11 tahun sebanyak 4 (29\%) anak. Sedangkan karies gigi molar pertama permanen berdasarkan jenis kelamin, perempuan sebanyak 61 (61\%) anak, laki laki sebanyak 45 ( 53\%) anak.
\end{abstract}

\section{Kata Kunci : Karies, Gigi Molar Pertama Permanen}

\begin{abstract}
The first permanent molar is a very susceptible caries. This is because the tooth is the first permanent tooth eruption, besides the anatomical form that has fit and fissure which in the easy stacking of food scraps and microorganisms that are difficult to clean by brushing teeth, making it easy for caries. Therefore, this research is titled Permanent First Molar Dental Caries on Elementary School Students 13 Palembang Year 2018. The purpose of this study is known images of caries permanent first molars in the Elementary School Students 13 Palembang Year 2018. Type of research Copyright (C) 2011 Unikom Center used is descriptive research with survey approach. The data analysis used is univariate analysis. The sampling of this research using purposive sampling method. The subjects of the study were children from grade I to V SD Negeri 13 Palembang totaling 185 children. The results of the study revealed the number of permanent permanent molar tooth caries by 106 (57\%) of children, the first permanent molar caries by age, 6 years as many as 1 (4\%) children, at age 7 years as many as 8 (47\%) children, year by age 44 (77\%), at the age of 9 years 31 (69\%) children, age 10 years 18 $(64 \%)$ children, and age 11 years $4(29 \%)$ children. While permanent first molars of permanent tooth by sex, female 61 (61\%) children, male as much as 45 (53\%) child.
\end{abstract}

Keywords: Caries, Permanent First Molar Teeth.

\section{PENDAHULUAN}

Karies merupakan penyakit yang banyak menyerang anak - anak terutama umur 6 sampai 9 tahun. Pada umur 6 tahun gigi molar permanen sudah mulai tumbuh sehingga lebih rentan terkena karies dan umur 9 tahun merupakan periode gigi bercampur dimana jumlah gigi permanen dan gigi sulung dalam rongga mulut hampir sama yaitu 14 gigi permanen dan 10 gigi sulung. (Liwe, Marsela, 2015 )

Karies pada gigi molar pertama permanen menjadi penyebab utama tingginya prevalensi pencabutan disebabkan karena gigi molar pertama adalah gigi yang pertama kali erupsi sehingga perilaku anak dalm memelihara kesehatan gigi masih kurang, serta bentuk anatomis dari gigi molar pertama yang memilki pit dan 
fissure yang menjadi tempat singgah sisa makanan. (Mintjelungan, Cristy. 2015 )

Prevalensi karies gigi geraham pertama permanen pada anak umur $8-10$ tahun merupakan jumlah atau presentase orang dalam satu populasi yang mengalami suatu penyakit karies gigi.Penyakit ini terjadi pada jaringan keras gigi, diikuti dengan kerusakan bahan organik yang dapat menyebabkan rasa ngilu hingga nyeri. Penyakit karies bersifat progresif dan kumulatif, bila dbiarkan tanpa disertai perawatan dalam kurun waktu tertentu kemungkinan akan bertambah parah. ( Silaban, Sinta ,dkk, 2015 )

Berdasarkan dari survei yang pernah dilakukan di SD Negeri 13 Palembang ini, Penulis melihat adanya setiap siswa yang memiliki gigi berlubang.Disamping itu belum adanya program UKGS yang dijalankan pada sekolah tersebut.

Tujuan penelitian adlah diketahuinya Gambaran Karies Gigi Molar Pertama Permanen Pada Siswa- Siswi di SD Negeri 13 Palembang. Penelitian ini bermanfaat meningkatkan mutu dan pelayanan kesehatan gigi dalam pendidikan kesehatan gigi mulut pada anak-anak dan dapat dijadikan sebagai bahan referensi dalam proses belajar mengajar (PBM) untuk meningkatkan kualitas kesehatan bagi siswa- siswinya.

\section{A. Konsep Dasar Gigi}

\section{Pengertian Gigi}

Gigi merupakan salah satu organ pengunyah yang terdiri dari gigi pada rahang atas dan rahang bawah, gigi terdiri dari tiga bagian yaitu mahkota gigi, akar gigi dan leher gigi. Gigi susu mulai tumbuh ketika bayi berumur 6 bulan setelah bayi berumur 2 tahun maka seluruh gigi yang berjumlah 20 buah sudah tumbuh sempurna ( Ramadhan, 2010)

Tanpa adanya gigi, manusia akan sulit memakan yang dimakannya. Menurut tugasnya, gigi termasuk dari sistem pencernaan.Gigi tumbuh didalam lesung pada rahang dan memiliki jaringan seperti pada tulang, tetapi gigi bukanlah bagian dari kerangka. Menurut perkembangannya, gigi lebih banyak persamaannya dengan kulit daripada dengan tulang. (Hidayat, 2016)

\section{Fungsi Gigi}

Gigi berfungsi dalam proses matrikasi( pengunyahan). Mengunyah ialah menggigit dan menggiling makanan diantara gigi atas dan bawah.Gerakan lidah dan pipi membantu dengan memindahkan makanan lunak ke palatum keras ensit gigi- gigi. Semua bagian tubuh manusia memiliki tugas, peran dan fungsi masingmasing, termasuk gigi juga memiliki beberapa fungsi, diantaranya:

a. Pengunyahan

Gigi berperan penting untuk menghalusakan makanan agar lebih mudah ditelan serta meringankan kerja proses pencernaan. Sangat tidak mungkin bila kita menelan utuh makanan tanpa dikunyah terlebih dahulu, dan kalaupun mungkin organ pencernaan akan bekerja sangat berat dan penyerapan makanan tidak akan maksimal.

b. Berbicara

Gigi sangat diperlukan untuk mengeluarkan atau melaflakan bunyi ataupun huruf- huruf tertentu, seperti misalnya huruf T, V, F, D, S. tanpa gigi, bunyi huruf- hruf ini tidak akan terdengar dengan sempurna. Dalam hal berbicara pun akan terdengar kurang atau bahkan tidak sempurna. 


\section{c. Estetik}

Sebuah senyum tidak akan lengkap tanpa hadirnya sederetan gigi yang rapi dan bersih. Hampir semua orang yang profesinya mengandalakan penampilan didepan orang banyak .

d. Menjaga kesehatan rongga mulut dan rahang

Banyak hal yang akan terjadi bila gigi kita hilang, diantaranya gangguan pengunyahan makanan, terutama pada susunan gigi yang tidak teratur ((malokluksi), tulang alveolar yang berkurang (resorpsi), gangguan pada sendi rahang,dan penyakit pada jaringan periodontal. ( Hidayat, Rachmat, 2016)

\section{Jenis Gigi}

Gigi geligi manusia termasuk golongan heterodont karena bentuknya bermacam- macam dan fungsinya pun berbeda- beda. Secara umum gigi bisa dibagi menjadi empat jenis :

a. Gigi insisif atau gigi seri

Gigi ini berbentuk persegi panjang, dan berfungsi untuk memotong makanan. Gigi insisif terletak di bagian paling depan di tengah lengkung gigi, ada empat buah di rahang atas maupun dirahang bawah.

b. Gigi kaninus atau gigi taring

Gigi taring berada disebelah gigi insisif.Gigi ini berbentuk lebih panjang dengan ujung yang runcing.Gigi tering berfungsi untuk mengoyak atau menyobek dan memotong makanan.Gigi taring berjumlah empat buah, dua dirahang atas dan dua dirahang bawah.

c. Gigi premolar atau gigi geraham kecil

Pada gigi premolar rahang atas mempunyai dua cups, rahang bawah hampir mirip dengan kaninus namun pada bagian cups tidak runcing dan juga lebih besar dari gigi kaninus. Tiap rahangnya berjumlah empat, berfungsi untuk menyobek dan membantu menghaluskan makanan.

d. Gigi molar atau gigi geraham besar Bentuknya seperti kotak dan ukurannya besar. Gigi molar merupakan gigi yang paling berperan dalam proses penghalusan makanan. Tottalnya ada dua belas buah,enam dirahang atas dan enam dirahang bawah.( Ramadhan,2010)

\section{Bagian Gigi}

Bagian gigi terdiri atas:

a. Mahkota gigi ( korona, crown ) merupakan bagian gigi yang dilapisi email/ dan normalnya terletak diluar jaringan gingiva.

b. Leher gigi (cenviks)

Line/ garis cervical/ pertemuan semento email merupakan batas antara bagian sementum dan email yang merupakan pertemuan anatara korona dan akar gigi.

c. Akar ( radix,root)

Bagian gigi yang dilapisi sementum (semen) dan didukung oleh tulang alveolar maksila dan mandibula.

Akar tunggal : satu akar dengan satu apeks

d. Akar multiple : banyak akar dengan bifurkasi ( tempat 2 akar bertemu)dan trifukasi ( tempat 3 akar bertemu).

e. Apeks (foramen apical)

Titik yang terujung dari suatu benda yang runcing atau yang berbentuk kerucut seperti akar gigi.( Deynilisa, saluna, 2016)

\section{B. Karies Gigi}

\section{Pengertian Karies Gigi}

Karies gigi merupakan suatu penyakit jaringan keras gigi, yaitu email, dentin dan sementum yang disebabkan oleh aktifitas suatu jasad renik dalam suatu karbohidrat yang dapat diragikan. Penyakit ini ditandai dengan terjadinya 
demineralisasi pada jaringan keras gigi yang kemudian diikuti oleh kerusakan bahan organiknya. Akibatnya, terjadi invasi bakteri dan kematian pulpa serta penyebaran infeksinya ke jaringan periapeks yang dapat menyebabkan nyeri (Gambar 1). Penyakit karies bersifat progresif dan kumulatif, bila dibiarkan tanpa disertai perawatan dalam kurun waktu tertentu kemungkinan akan bertambah parah. Walaupun demikian, mengingat mungkinnya remineralisasi terjadi pada stadium yang sangat dini penyakit ini dapat dihentikan.( Kidd E, 2013).

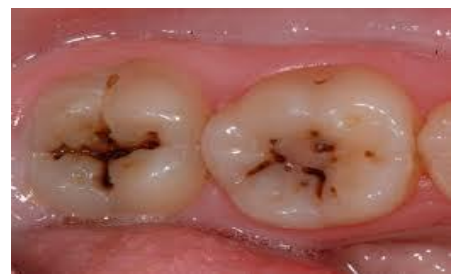

Gambar 1 Karies gigi (Sumber : Fian, 2010)

\section{Etiologi Karies Gigi}

Faktor penyebab karies gigi terdiri dari penyebab dalam individu dan penyebab luar individu (Gambar 2). Faktor dalam penyebab karies gigi adalah faktor di dalam mulut yang berhubungan langsung dengan proses terjadinya karies gigi antara lain host, mikroorganisme, substrat, dan waktu. Sedangkan faktor luar individu adalah status ekonomi, keluarga, pekerjaan, fasilitas kesehatan gigi dan pendidikan kesehatan gigi yang pernah diterima. ( Rahmawati I, 2011).

Selain faktor- faktor yang ada didalam mulut yang langsung berhubungan dengan karies, terdapat faktor- faktor yang tidak langsung yang disebut faktor resiko luar, yang merupakan faktor predisposisi dan faktor penghambat terjadinya karies. Faktor luar antara lain adalah usia, jenis kelamin, tingkat pendidikan, tingkat ekonomi, lingkungan, sikap dan perilaku yang berhubungan dengan kesehatan gigi. Ada dua faktor yaitu faktor dalam dan faktor luar yaitu :

\section{a. Faktor Dalam}

\section{1) Mikroorganisme}

Mikroorganisme merupakan faktor paling penting dalam proses awal terjadinya karies. Mereka memfermentasi karbohidrat untuk memproduksi asam.Plak gigi merupakan lengketan yang berisi bakteri produk- produknya, yang terbentuk pada semua permukaan gigi.Akumulasi bakteri ini tidak terjadi secara kebetulan melainkan terbentuk melalui serangkaian tahapan.

Asam terbentuk dari hasil fermentasi sakar diet oleh bakteri di dalam plak gigi. Sumber utamanya adalah glukosa yang masuk dalam plak gigi, sedangkan kuantitatif, sumber utama glukosa adalah sukrosa. Penyebab utama terbentuknya asam tadi adalah S.Mutans serotipe c yang terdapat di dalam plak karena kuman ini memetabolisme sukrosa menjadi asam lebih cepat dibandingkan kuman lain (Kidd E, 2013).

\section{2) Host}

Terbentuknya karies gigi diawali dengan terdapatnya plak yang mengandung bakteri pada gigi.Oleh karena itu kawasan gigi yang memudahkan pelekatan plak sangat memungkinkan diserang karies. Kawasan-kawasan yang mudah diserang karies tersebut adalah :

a. Pit dan fisur pada permukaan oklusal molar dan premolar; pit bukal molar dan pit palatal insisif.

b. Permukaan halus di daerah aproksimal sedikit di bawah titik kontak.

c. Email pada tepian di daerah leher gigi sedikit di atas tepi gingiva.

d. Permukaan akar yang terbuka, yang merupakan daerah tempat melekatnya 
plak pada pasien dengan resesi gingiva karena penyakit periodonsium.

e. Tepi tumpatan terutama yang kurang atau mengeper.

f. Permukaman gigi yang berdekatan dengan gigi tiruan dan jembatan.

\section{3) Substrat}

Penelitian menunjukkan bahwa makanan dan minuman yang bersifat fermentasi karbohidrat lebih signifikan memproduksi asam, diikuti oleh demineralisasi email.Tidak semua karbohidrat benar-benar kariogenik. Produksi polisakarida ekstraseluler dari sukrosa lebih cepat dibandingkan dengan glukosa, fruktosa, dan laktosa. Sukrosa merupakan gula yang paling kariogenik, walaupun gula lain juga berpotensi kariogenik (Taringan, 2014)

\section{4) Waktu}

Adanya kemampuan saliva untuk mendepositkan kembali mineral selama berlangsungnya proses karies, menandakan bahwa proses karies tersebut terdiri dari saliva ada di dalam lingkungan gigi, maka karies tidak menghancurkan gigi dalam hitungan hari atau minggu, melainkan dalam bulan atau tahun. Dengan demikian sebenarnya terdapat kesempatan yang baik untuk menghentikan penyakit ini (Kidd E, Sally J:2013).

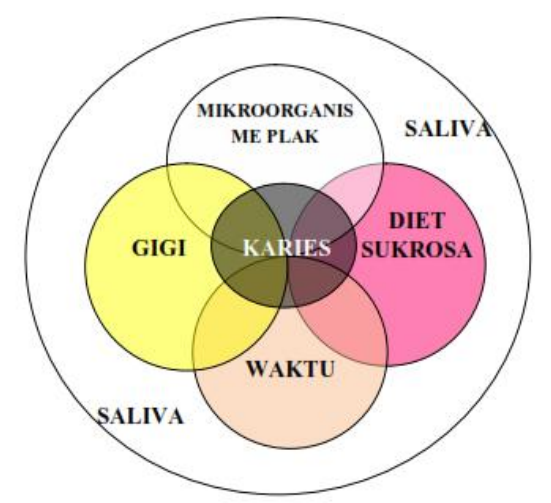

Gambar 2 Faktor Terjadinya Karies( Sumber :Fian 2010)

\section{b. Faktor Luar}

Beberapa faktor luar individu penyebab terjadinya karies gigi, yaittu : (Tarigan, 2014 )

\section{1) Ras}

Amat sulit menentukan pengaruh ras terhadap terjadinya karies gigi.Namun, keadaan tulang rahang suatu ras bangsa mungkin berhubungan dengan presentase karies yang semakin meningkat atau menurun.Misalnya, pada ras tertentu dengan rahang sempit sehingga gigi geligi pada rahang sering tumbuh tak teratur. Dengan keadaan gigi yang tidak teratur ini akan mempersulit pembersihan gigi, dan ini akan mempertinggi persentase karies pada ras tersebut.

\section{2) Jenis Kelamin}

Dari pengamatan yang dilakukan oleh Milhahn-Turkeheim yang dikutip dari Tarigan pada gigi M1, didapat hasil bahwa persentase karies gigi pada wanita lebih tinggi dibanding denga pria.Dibanding dengan molar kanan, persentase karies molar kiri lebih tinggi karena faktor penguyahan dan pembersihan dari masingmasing bagian gigi.

\section{3) Usia}

Sepanjang hidup dikenal 3 fase umur dilihat dari gigi-geligi :

1). Periode gigi campuran, disini molar 1 paling sering terkena kariesAnak usia 6-12 tahun masih kurang mengetahui dan mengerti bagaimana cara memelihara kebersihan gigi dan mulut. Anak-anak usia sekolah perlu mendapat perhatian khusus sebab pada usia ini anak sedang menjalani proses tumbuh kembang. (Tarigan, 2014 )

\section{4) Makanan}

Makanan sangat berpengaruh terhadap gigi dan mulut, pengaruh ini dapat dibagi mejadi 2, yaitu:

1. Komposisi dari makanan yang menghasilkan energi. 
Misalnya, karbohidrat, protein, lemak, vitamin, serta mineral-mineral.Unsurunsur tersebut berpengaruh pada masa pra-erupsi serta pasca-erupsi dari gigi geligi.

2. Fungsi mekanis dari makanan yang dimakan.

Makanan yang bersifat membersihkan gigi. Jadi, makanan merupakan penggosok gigi alami, tentu saja akan mengurangi kerusakan gigi. Makanan bersifat membersihkan gigi ini adalah apel, jambu air, bengkuang, dan lain sebagainya.Sebaliknya makananmakanan yang lunak dan melekat pada gigi amat merusak gigi, seperti bonbon, coklat, biskuit, dan lain sebagainya. Karies terjadi ketika proses remineralisasi menjadi lebih lambat dibandingkan proses demineralisasi.

Remineralisasi gigi dapat terjadi pada $\mathrm{pH}$ lingkungan yang bersifat:

a. Sedikit jumlah bakteri kariogenik

b. Keberadaan fluoride

c. Gagalnya substansi penyebab metabolisme bakteri

d. Peningkatan sekresi saliva

e. Kemampuan buffer yang tinggi

\section{Bentuk Karies Gigi}

Karies gigi juga dibagi menjadi berbagai macam bentuk karies, di dalam buku rasitna tarigan :

a. Berdasarkan kedalaman karies terbagi menjadi 3 yaitu:

1) Karies superfisialis : karies baru mengenai email saja, sedang dentin belum terkena.

2) Karies Media

Karies sudah mengenai dentin, tetapi belum melebihi setengah dentin

3) Karies Profunda

Karies sudah mengani lebih dari setengah dentin dan kad ang-kadang sudah mengenai pulpa.karies profunda ini dapat kita bagi lagi menjadi:

a) Karies profundaa stadium I. Karies telah melewati setengah dentin, biasanya radang pulpa belum dijumpai.

b) Karies profunda stadium II. Masih dijumpai lapisan tipi $\mathrm{s}$ yang membatasi karies dengan pulpa. Biasanya di sini telah terjadi radang pulpa.

c) c ) Karies profunda stadium III. Pulpa telah terbuka dan dijumpai bermacam-macam radang pulpa.

b. Menurut lama Jalannya Karies

1) Karies akut

Proses karies berjalan cepat sehingga badan tidak sempat membuat perlawanan. Karies terus berjalan sampai ke ruang pulpa.

2) Karies kronis

Proses karies terlambat, badan masih sempat membuat pertahanan dengan adanya daerah berwarna kehitam hitaman dan keras Karena adanya endapan kapur .

3) Senile caries

Terdapat pada orang tua, sering pada bagian servikal gigi karena atrofi ( fisiologis) gusi sehingga akar terlihat mudah terjadi karies gigi.

\section{4) Rampant caries}

Proses karies ini tidak dapat dikontrol karena jalannya sangat cepat. (Deynilisa, Saluna, 2016) 


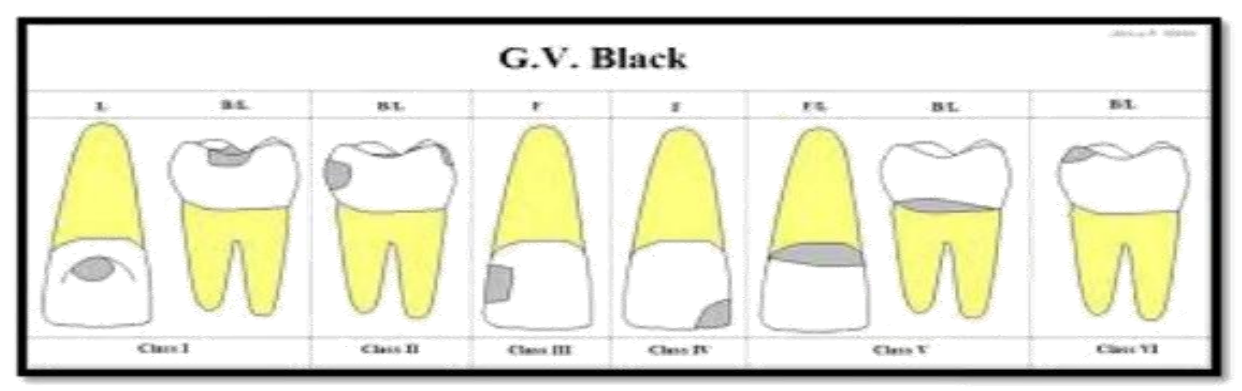

Gambar 3 Klasifikasi G.V. Black

\section{Klasifikasi Karies}

Klasifikasi karies menurut G.V. Black ( 1924) dibagi menjadi 5 kelas yang diuraikan dibawah ini Gambar 3 :

1) Kelas I

a. karies yang terdapat pada bidang oklusal pada gigi premolar dan molar.

b. karies pada ceruk dan fisura bukal molar bawah.

c. karies pada ceruk dan fisura palatinal molar atas.

d. karies pada bagian palatal atau lingual gigi depan.

2) kelas II

Karies yang terjadi pada bagian aproksimal baik bagian mesial atau distal dari gigi posterior.

3) Kelas III

Karies pada bagian aproksimal gigi anterior ( insisif dan kaninus ), bagian mesial maupun distal yang tidak mengenai (tepi insial).

4) Kelas VI

Karies pada bidang aproksimal insisif dan kaninus baik bagian mesial maupun distal yang sampai mengenai tepi insisal.

5) Kelas V

Karies yang terdapat pada sepertiga servikal semua gigi. Gigi terdiri dari tiga bagian sepertiga insisal ,sepertiga tengah, sepertiga servikal.
6) Kelas VI

Karies pada bagian puncak tonjol semua gigi.

\section{Faktor Terjadinya Karies}

Terjadinya karies dipengaruhi oleh bermacam - macam faktor antara lain adalah faktor:

a. Gigi

1) Komposisi: susunan zat yang membentuk gigi dapat dipengaruhi karies. Misalnya, pada gigi yang saat pembentukkannya kekurangan vitamin, mineral, dan sebagainya.

2) Posisi: letak gigi dalam lengkungannya. Misalnya, gigi yang berdesak - desakan memudahkan tertimbunnya sisa - sisa makanan dan mempermudah terjadinya karies.

3) Morfologi: bentuk gigi, misalnya gigi yang permukaan oklusalnya mempunyai banyak ceruk dan fissure yang dalam akan memudahkan tertimbunnya sisa makanan.

b. Saliva

1) Banyaknya saliva: saliva berfungsi membersihkan, namun tiap - tiap orang tidak sama jumlah air ludah yang dikeluarkannya.

2) sifat bakterisida: didalam saliva terdapat zat enzim yang mempunyai daya mematikan bakteri. Jumlahnya banyak dan potensinya tidak sama pada setiap orang. 
c. Diet

1) macam makanan: makanan yang mengandung gula terutama refined carbohidrat.

2) bentuk makanan: makanan yang mengandung serat membantu membersihkan gigi ( self cleansing food), misalnya bengkuang, apel, jambu dll.

\section{Akibat Dari Karies Gigi}

Jika karies belum menembus email gigi, maka belum terasa apa-apa. Tapi jika sudah mencapai lapisan dentin biasanya akan merasakan rasa ngilu. Proses pembentukan karies ini akan berlanjut bertambah besar dan bertambah dalam. Lubang gigi yang besar ini akan menjadi jalan masuk bakteri-bakteri yang ada didalam mulut untuk menginfeksi jaringan pulpa gigi tersebut yang akan menimbulkan rasa sakit berdenyut sampai ke kepala, begitu juga apabila gigi tersebut terkena rangsangan dingin, panas, makanan yang manis dan asam.

Pada tahap awal karies gigi walaupun tidak menimbulkan keluhan harus segera dirawat, karena penjalaran karies mula-mula terjadi pada email. Bila tidak segera dibersihkan dan tidak segera ditambal, karies akan menjalar ke lapisan dentin hingga sampai ke ruang pulpa yang berisi pembuluh saraf dan pembuluh darah, sehingga menimbulkan rasa sakit dan akhirnya gigi tersebut bisa mati.

Pada tahap lanjut, selain menimbulkan keluhan yang cukup menggangu, maka apabila tetap dibiarkan tanpa perawatan, proses karies akan semakin berlanjut sehingga akan merusak jaringan pulpa/syaraf gigi. Pada tahap seperti ini dapat disertai timbulnya bau mulut (halitosis) sehingga menggangu pergaulan. Jika kavitas sudah terlalu dalam dann menyebabkan pulpa terinfeksi, lama- kelamaan pulpa akan mati. Bakteri-bakteri ini akan terus menginfeksi jaringan dibawah gigi dan menimbulkan periodontitis apikalis yaitu peradangan jaringan periodontal disekitar ujung akar gigi. Apabila tidak dirawat kondisi tersebut akan bertambah parah sampai terbentuk abses periapikal (terbentuknya nanah didaerah apeks gigi atau didaerah ujung akar), granuloma, sampai kista gigi (Ramadhan, 2010).

\section{Pencegahan Karies Gigi}

Menurut Putri (2012) Pencegahan karies gigi bertujuan untuk mempertinggi taraf hidup dan memperpanjang kegunaan gigi didalam mulut melalui cara sebagai berikut:

a. Mempertinggi resistensi gigi terdapat deklasifikasi, dengan cara:

1) Menambahkan fluor dalam jumlah yang sesuai di dalam air minum terutama sebelum gigi erupsi

2) Aplikasi fluor topikal, pasta gigi yang mengandung fluor atau berkumur dengan larutan fluor

b. Menghalangi pembentukan dan menghilangkan dengan segera faktor penyerang di sekitar gigi.

c. Memperbanyak makanan yang menyehatkan gigi. Jenis makanan yang membantu membersihkan gigi, seperti buah-buahan dan sayur-sayuran.

d. Melakukan kontrol ke tenaga kesehatan gigi 6 bulan sekali.

\section{Perawatan Karies Gigi}

a. Penambalan (Filling)

Untuk mencegah proses karies lebih lanjut, perawatan penambalan adalah salah satu cara yang dilakukan terutama pada karies yang ditemukan pada email dan dentin ( Ramadhan, 2010 ).

b. Perawatan Saluran Akar

Dilakukan bila sudah terjadi pulpitis atau peradangan. Dimana karies sudah 
mencapai pulpa. Tahap pertama yang dilakukan adalah mematikan saraf supaya tidak menimbulkan rasa sakit, selanjutnya membuang dan membersihkan jaringan pulpa, saraf, dan pembuluh darah yang terinfeksi untuk dilakukan pengisian saluran akar yang diatasnya diletakkan tambalan sementara baru kunjungan berikutnya dapat dilakukan penambalan permanen atau pembuatan mahkota tiruan.

c. Pencabutan Gigi

Pencabutan gigi adalah suatu prosedur pengangkatan atau pengembalian gigi dari tempatnya dalam mulut.Pencabutan gigi dapat dilakukan karena berbagai macam seperti pada gigi berlubang atau dengan kerusakan yang terlalu parah sehingga tidak dapat direstorasi (Pratiwi, 2009).

\section{Gigi molar Pertama Permanen Pada Anak}

Gigi tetap adalah gigi terbesar diantara gigi - geligi susu dan ini baru erupsi setelah pertumbuhan dan perkembangan rahang sudah cukup memberi tempat untuk tumbuhnya gigigeligi tetap. Gigi yang pertama muncul dalam rongga mulut/ erupsi ialah gigi molar pertama permanen ( geraham ), tumbuh pada usia enam tahun dan sering juga disebut six year molar.

Gigi molar pertama permanen merupakan gigi tetap yang pertama muncul dalam rongga mulut/ erupsi, yang letaknya distal dari gigi molar kedua sulung.Gigi tersebut mulai terklasifikasi pada saat bayi dilahirkan. Gigi ini adalah gigi yang terbesar diantara gigi geligi susu dan gigi ini baru erupsi setelah pertumbuhan dan perkembangan rahang sudah cukup memberi tempat untuknya. ( Itjiningsih, 2012).
Molar gigi molar pertama permanen (geraham) adalah gigi keenam dari garis median.Pada umumnya gigi ini adalah gigi yang terbesar, yang berfungsi untuk susunan gigi geligi.Gigi molar pertama permanen rahang atas erupsi pada umur $6-7$ tahun dan pembentukan akar gigi lengkap pada umur 9 - 10 tahun, demikian pula pada gigi molar pertama permanen rahang bawah.( Indriyanti, pertiwi, 2014).

Masih banyak gigi molar pertama permanen terserang karies segera setelah erupsi. Pada usia 10 tahun $62 \%$ pada anak - anak yang mengalami kerusakan gigi tersebut. Tingginya prevalensi karies gigi molar pertama permanen antara lain dikaitkan dengan permukaan oklusal gigi tersebut memiliki pit dan fissure yang dalam dan disertai oral hygine anak yang buruk, pit dan fisur pada gigi posterior sangat rentan terhadap karies karena sisa sisa makanan mudak menumpuk di daerah tersebut.( Pratama, 2012)

Sebagian besar karies menyerang gigi tetap pertama ( molar pertama ). Gigi tetap pertama. Gigi molar pertama rahang atas dan rahang bawah tumbuh pada usia 6 tahun. Gigi tetap tersebut tidak menggantikan gigi susu manapun dan letaknya dibelakang. Hampir semua orang tua berfikir gigi tersebut akan diganti, dan akibat pembersihan gigi yang kurang hampir 50\% gigi molar pertama pada anak - anak di usia 8 tahun gigi tersebut sudah karies atau lubang. ( Syamsul, BI, 2012 )

a. Molar Pertama Atas

Gigi adalah gigi keenam dari garis median dirahang atas.Pada umumnya gigi ini adalah gigi yang terbesar dirahang atas. Gigi ini mempunyai 4 cups, yang bertumbuh baik dan 1 cups tambahan yang disebut cups ke - 5 atau cups carabeli, cups terakhir ini, terdapat pada bagian palatl dari cups mesiopalatal, yang terbesar 
sehingga tak dapat terlihat. Secara normal gigi ini mempunyai 3 akar yang bertumbuh baik dan jelas terpisah pada apeksnya.( Pratiwi, 2009 )

b. Masa Erupsi Gigi Molar Pertama Tetap

Erupsi gigi merupakan suatu perubahan posisi gigi yang diawali dengan pertumbuhan dalam tulang rahang melalui beberapa tahap melalui beberapa tahap berturut - turut hingga mencapai posisi fungsional didalam rongga mulut gigi molar pertama mulai erupsi pada usia $6-7$ yang merupakan gigi permanen pertama erupsi yang disebut six year molar. Gigi ini bukan gigi pengganti, artinya gigi ini langsung muncul pada deretan dibelakang gigi susu, baik pada rahang atas maupun rahang bawah.( Pratiwi, 2009).

\section{Mekanisme Karies Gigi Terhadap Gigi Molar Pertama Permanen}

Gigi yang paling sering terkena karies adalah molar pertama permanen. Gigi molar pertama permanen merupakan gigi yang penting pada melihat gambaran tentang suatu keadaan secara objektif dalam waktu tertentu.

Pendekatan Survey yang digunakan dalam penelitian ini adalah mobidirty survey.yaitu untuk mengetahui kejadian dan distribusi penyakit ( karies) populasi tersebut dan sekaligus untuk mengetahui kejadian suatu penyakit ( karies ). (Notoatdmojo, 2012).

\section{METODE PENELITIAN}

Jenis penelitian yang akan digunakan pada penelitian ini deskriptif yaitu suatu penelitian yang bertujuan untuk mengunyah , menumbuk dan menggiling makanan karena mempunyai permukaan kunyah yang lebar dan banyak tonjolantonjolan dan lekukan - lekukan. Gigi molar pertama permanen (geraham ) terserang karies setelah erupsi dimasa kanak- kanak (Itjingningsih, 2012).Sampel dalam penelitian ini adalah siswa - siswi Sekolah Dasar Negeri 13 Palembang kelas I sampai V yang berjumlah 185 siswa.

\section{Analisa Data}

Analisa data pada penelitian ini adalah analisa univariat yang dilakukan terhadap tiap variabel dari hasil penelitian.Dan menghasilkan distribusi dan frekunsi dari tiap variabel dan disajikan (Notoatdmojo, 2012).

\section{HASIL}

Berdasarkan hasil penelitian pada siswa - siswi di SDN 13 Palembang yang dilakukan pada bulan April tahun 2018 dengan menggunakan sampel sebanyak 185 orang.Analisa ini menggunakan analisa unavariat yang dilakukan untuk mengetahui Gambaran Karies Gigi Molar Pertama Permanen pada siswa - siswi SDN 13 Palembang tahun 2018. Dari data ini dapat diketahui prevalensi karies gigi molar pertama permanen pada anak SDN 13 Palembang tahun 2018 sebagai berikut:

$$
\begin{aligned}
& 106 \\
& \text { Prevalensi }=\quad \mathrm{X}_{100 \%}=57 \% \\
& 185
\end{aligned}
$$

Dari data disajikan dalam bentuk tabel distribusi berdasarkan kriteria sebagai berikut :

Tabel 1 Distribusi Frekuensi Karies M1 pada Siswa Sekolah Dasar Negeri 13 Palembang Tahun 2018

\begin{tabular}{llll}
\hline No & $\begin{array}{l}\text { Prevalensi } \\
\text { Kejadian } \\
\text { Karies }\end{array}$ & N & Persentase \\
\hline $\mathbf{1}$ & Karies & $\mathbf{1 0 6}$ & $\mathbf{5 7 \%}$ \\
\hline $\mathbf{2}$ & Tidak Karies & $\mathbf{7 9}$ & $\mathbf{4 3 \%}$ \\
\hline & Total & $\mathbf{1 8 5}$ & $\mathbf{1 0 0} \%$ \\
\hline
\end{tabular}

Sumber : Data Primer, 2018 
Dari tabel 1Hasil penelitian ini menyatakan bahwa prevalensi pada anak di SDN 13 Palembang jumlah kejadian karies lebih tinggi sebanyak 106 ( 57\%) dibandingkan tidak karies sebanyak 79 (43 $\%)$, dikarenakan kurangnya kesadaran anak mengenai pentingnya menjaga kesehatan gigi dan mulut serta dilihat dari jajanan di lingkungan sekolah anak-anak banyak mengkonsumsi makanan yang manis dan lengket dan juga minuman ringan yang mengandung bahan pemanis dan asam. Hasil ini dapat diketahui pada saat peneliti melakukan penelitian sehingga hal tersebut dapat timbulnya jumlah karies yang tinggi pada anak SDN 13 Palembang.

Tabel2 Distribusi Frekuensi Karies M1Berdasarkan Usia pada Siswa Sekolah Dasar Negeri 13 Palembang Tahun 2018

\begin{tabular}{|c|c|c|c|c|c|}
\hline No & $\begin{array}{l}\text { Usia ( } \\
\text { tahun) }\end{array}$ & $\mathbf{N}$ & $\begin{array}{c}\text { karies } \\
\text { M1 }\end{array}$ & $\begin{array}{c}\text { Tidak } \\
\text { karies } \\
\text { M1 }\end{array}$ & Total \\
\hline & & & $\mathbf{N}(\%)$ & $\mathbf{N}(\%)$ & $(\%)$ \\
\hline \multirow[t]{2}{*}{1} & 6 & 24 & 14 & 23 & \\
\hline & Tahun & & $\%$ & $96 \%$ & $100 \%$ \\
\hline \multirow[t]{2}{*}{2} & 7 & 17 & 8 & $953 \%$ & \\
\hline & Tahun & & $47 \%$ & & $100 \%$ \\
\hline \multirow[t]{2}{*}{3} & 8 & 57 & 44 & $1323 \%$ & \\
\hline & Tahun & & $77 \%$ & & $100 \%$ \\
\hline \multirow[t]{2}{*}{4} & 9 & 45 & 31 & 14 & \\
\hline & Tahun & & $69 \%$ & $31 \%$ & $100 \%$ \\
\hline \multirow[t]{2}{*}{5} & 10 & 28 & 18 & 10 & \\
\hline & Tahun & & $64 \%$ & $38 \%$ & $100 \%$ \\
\hline \multirow[t]{3}{*}{6} & 11 & 14 & 4 & 10 & \\
\hline & Tahun & & $29 \%$ & $71 \%$ & $100 \%$ \\
\hline & Total & 185 & 106 & 79 & \\
\hline
\end{tabular}

Berdasarkan tabel 2 Hasil peneleitian ini menyatakan jumlah usia mengalami karies M1 lebih Tinggi pada usia 8 tahun berjumlah 44 anak (77\%). Usia 6 tahun yang mengalami karies sebanyak 1 anak (4\%) anak termasuk paling sedikit terkena karies, usia 7 tahun yang mengalami karies sebanyak 8 anak
(47 \%), usia 9 tahun yang mengalami karies sebanyak 31 anak (69\%), usia 10 tahun yang mengalami karies sebanyak 18 anak ( 64\%) sedangkan pada usia 11 tahun yang mengalami karies sebanyak 4 anak ( $29 \%)$.

Tabel 3 Distribusi Frekuensi Karies M1Berdasarkan Jenis Kelamin pada Siswa Sekolah Dasar Negeri 13 Palembang Tahun 2018

\begin{tabular}{|c|c|c|c|c|c|}
\hline $\mathbf{N}$ & $\begin{array}{c}\text { Jenis } \\
\text { Kelamin }\end{array}$ & $\mathbf{N}$ & $\begin{array}{c}\text { karies } \\
\text { M1 }\end{array}$ & $\begin{array}{c}\text { tidak } \\
\text { karies } \\
\text { M1 }\end{array}$ & Total \\
\hline & & & $\mathbf{N}(\%)$ & $\mathbf{N}(\%)$ & $(\%)$ \\
\hline 1 & Laki - Laki & 85 & $\begin{array}{c}4553 \\
\%\end{array}$ & $\begin{array}{c}4047 \\
\%\end{array}$ & $100 \%$ \\
\hline 2 & Perempuan & 100 & $\begin{array}{c}61 \\
61 \%\end{array}$ & $\begin{array}{c}3939 \\
\%\end{array}$ & $100 \%$ \\
\hline & Total & 185 & 106 & 79 & $100 \%$ \\
\hline
\end{tabular}

Dari tabel 3. Hasil penelitian ini menyatakan jumlah anak Perempuan lebih banyak mengalami karies dibandingkan anak laki- laki, dikarenakan erupsi gigi anak perempuan lebih cepat dibandingkan dengan anak laki - laki dan disebabkan oleh faktor hormon juga yang mempengaruhi karies pada anak perempuan. Pada umumnya karies pada anak perempuan juga disebabkan oleh ketidakseimbangannya pola makan terutama yang mengandung karbohidrat (Silaban, Sinta, 2015)

\section{PEMBAHASAN}

Dari hasil tabel 1 penelitian terhadap siswa - siswi SD Negeri 13 Palembang tahun 2018, dengan sampel sebanyak 185 anak didapat hasil 106 anak yang mengalami karies dengan persentase $57 \%$. Hal ini dikarenakan anak - anak terlalu sering mengkonsumsi makanan mengandung gula yang tinggi seperti coklat, permen, biskuit ditambah lagi oleh kurangnya kesadaran anak untuk untuk 
menjaga kebersihan giginya setelah makan makanan yang tinggi kandungan gula, dan menjaga pola hidup bersih dan sehat.

Dari tabel 2 dapat disimpulkan bahwa siswa sekolah dasar Negeri 13 Palembang karies gigi molar pertama permanen berdasarkan usia sebanyak 106 yang mengalami karies pada usia 8 tahun lebih tinggi berjumlah 44 anak (77\%) sedangkan usia 9 tahun yang mengalami karies sebanyak 31 anak (69\%). perbedaan angka jumlah karies pada 8 dan 9 tahun tidak begitu berbeda jauh hal ini dikarenakan anak belum mampu untuk menjaga kebersihan gigi dan mulut sehingga dengan pit dan fissure yang dalam pada oklusal menjadi penumpukan sisa makanan dan mikroorganisme sehingga produksi asam oleh bakteri akan lebih cepat dan menimbulkan lubang pada gigi. Menurut Mc Donald (2011) Mengemukakan bahwa tingginya permukaan oklusal gigi molar pertama permanen pada anak usia 9 disebakan karena periode erupsi yang pendek, lebih lanjut lagi dijelaskan bahwa gigi molar pertama permanen adalah gigi yang paling pertama erupsi dalam pertumbuhan gigi permanen sehingga menjadi penentu bagi sisa gigi permanen yang belum erupsi.

Pada usia $6-7$ tahun yang mengalami karies sebesar $51 \%$ hal ini disebabkan kurangnya memperhatikan kebersihan gigi dan mulutnya dikarenakan ketidaktahuaan anak - anak tentang tumbuhnya gigi molar pertama permanen, sehingga mereka beranggapan bahwa gigi tersebut gigi sulung yang nantinya akan digantikan oleh gigi permanen, gigi molar pertama permanen sebagai gigi permanen yang pertama kali gigi erupsi dalam rongga mulut, gigi 16, 26, 36, 46 merupakan gigi tetap dan tidak akan berganti gigi baru lagi,. Hal ini menandakan bahwa karies dapat terjadi pada siapapun tanpa mengenal usia, hanya saja karies yang tidak dilakukan perawatan sebelumnya semakin lama semakin parah. Seseoranssg yang mengalami karies sering tidak menyadari bahwa ia mengalami karies karena belum merasakan sakit, akibatnya karies tidak dirawat dan bertambah parah hingga akhirnya gigi dicabut. ( Bahar, 2011 ).

Data tabel 5.3 dapat disimpulkan bahwa berdasarkan jenis kelamin, siswa perempuan SDN 13 Palembang memiliki jumlah karies lebih tinggi di bandingkan laki - laki. pada perempuan yang terkena karies sebanyak 61 siswi dengan persentase ( $61 \%$ ), sedangkan pada laki laki sebanyak 45 siswa dengan persentase ( $53 \%$ ). Hal ini terjadi karena siswi perempuan yang mengalami karies disebabkan faktor hormon, dimana perempuan memiliki hormon estrogen yang yang meningkat pada siklus menstruasi, dan pubertas, seiring meningkatnya hormon estrogen maka angka karies pun meningkat ( Ratu, A,J, 2015)umumnya disebabkan oleh ketidak seimbangannya pola makan terutama yang mengandung karbohidrat. Bakteri yang terdapat dalam plak bisa mengubah gula atau karbohidrat yang berasal dari makanan dan minuman menjadi asam yang bisa merusak gigi dengan cara melarutkan mineral - mineral yang terdapat pada gigi, proses hilangnya mineral dari struktur gigi dinamakan demineralisasi. (Ramadhan, 2010 )

\section{KESIMPULAN}

Prevalensi yang mengalami karies sebanyak 106 anak dengan persentase (57\%) dan yang tidak mengalami karies sebanyak 79 anak dengan persentase sebanyak (43\%) .Gambaran karies gigi 
molar pertama permanen berdasarkan Usia lebih banyak menderita karies pada usia usia 8 tahun berjumlah 44 anak ( $77 \%$ ). Usia 6 tahun yang mengalami karies sebanyak 1 anak ( $4 \%$ ) anak termasuk paling sedikit terkena karies, usia 7 tahun yang mengalami karies sebanyak 8 anak (47 \%), usia 9 tahun yang mengalami karies sebanyak 31 anak (69\%), usia 10 tahun yang mengalami karies sebanyak 18 anak ( 64\%) sedangkan pada usia 11 tahun yang mengalami karies sebanyak 4 anak ( $29 \%)$.

\section{DAFTAR PUSTAKA}

Bahar, A. 2011.Paradigma Baru Pencegahan Karies Gigi. Lembaga Penerbit Fakultas ekonomi universitas Indonesia: Jakarta

Budiharto. 2008. Metodologi Penelitian Kesehatan. Jakarta: EGC

Deynilisa, Saluna. 2016. Ilmu Konservasi Gigi. Jakarta: EGC

Edwina,Kidd dan Sally Joyston. 2013.

Dasar - Dasar Karies. Jakarta : EGC

Fian, M. 2010. Gambar Karies. http://kariesgigidanpencegahan.co $\underline{m}$ diakses pada 15 Januari 2018.

G.V. Black. 1924. Klasifikasi Karies .terjemahan oleh : Deynilisa, Saluna, Jakarta: EGC

Hasvinasofrullah.2016.https://hasvinasofr ullah.wordpress.com/2016/11/01/k aries-gigi/ diakses pada 15 Januari 2018.

Hidayat, Rahcmat. 2016. Kesehatan gigi dan mulut. Yogyakarta: Andi.

Indriyanti, pertiwi. 2014.Jurnal. Pola Erupsi Gigi Permanen ditinjau dari usia Kronologis Pada Anak Usia 6 sampai 12 Tahun di Kabupaten
Sumedang. FKG Universitas Padjadjaran, ( 7 Februari 2018 ).

Itjingningsih.2012. Anatomi Gigi. Jakarta: EGC

Liwe, Marsela.2015. Prevalensi Karies Gigi Molar Satu Permanen Pada Anak Umur 6 - 9 Tahun Di Sekolah Dasar Kecamatan Temohon Selatan. Jurnal Kesehatan Gigi Volume 3 No 2,Manado diakses pada 15 Januari 2018.

Mc Donald RE, Avery, DR, Dental caries in child and adolescent, in dentinstry for the child and adolescent.Edt. 2010

Mintjelungan, Cristy. 2015. Gambaran Karies Gigi Molar Pertama Permanen dan Status Gizi Di SD Katolik 06 Manado. Jurnal Kesehatan Gigi Volume 3 No 2,Manado diakses pada 15 Januari 2018.

Notoatmodjo, Soekidjo. 2012. Metodologi Penelitian Kesehatan. Jakarta : Rineka Cipta.

Palomino, Michel. 2009. Klasifikasi Karies .From ://www.med-etc.com $\mathrm{med} / \mathrm{merk} / \mathrm{merk} \quad$ blattzahnkaries.html diakses pada tanggal 15 januari 2018.Pedia , Biologi. 2011. http://biologipedia.blogspot.co.id/2 011/01/struktur-gigi.html diakses pada 15 Januari 2018.

Pratama, 2012.Usaha Pencegahan Terhadap Perkembangan Karies Pada Pit dan Fisur.http://www.adifkgugm.com/2 012/02/usaha-terhadapperkembangan.html. ( diakses Rabu, 7 februari 2018)

Pratiwi, D. 2009. Gigi Sehat.Jakarta: Kompas Media Nusantara 
Putri, Megananda Hiranya, dkk. 2012. Ilmu Pesncegahan Penyakit Jaringan Keras dan Jaringan Pendukung Gigi.Jakarta : EGC

Silaban, Sinta, dkk. 2015. Prevalensi Karies Gigi Geraham Pertama Permanen Pada Anak Umur 8 - 10 Tahun di SD Kelurahan Kawangkoan Bawah.Diakses pada 15 Januari 2018.

Soebroto, Ikhsan. 2009. Apa Yang Tidak Dikatakan Dokter Tentang Kesehatan Gigi Anda. BOOKMARKS : Yogyakarta

Syamsul, BI. 2012. Prevalensi Karies Gigi Molar Pertama Permanen Pada murid - murid Sekolah Dasar di Kecamtan Tamalanrea. Volume 3 No 2,Manado diakses pada 20 Januari 2018.

Ramadhan, A.D. 2010. Serba-Serbi Kesehatan Gigi dan Mulut.Bukune. Jakarta.

Ratu, A, J. 2013.Hubungan Antara Status Kebersihan Mulut dengan Karies Siswa Sekolah Menengah Atas Negeri 1 Manado.Diakses pada 26 juni 2018.

Tarigan, Rasinta. 2014. Karies Gigi. Jakarta: EGC 